\title{
GMR
}

\section{Genetic diversity and pectinolytic activity of epiphytic yeasts from grape carposphere}

\author{
M. Cilião Filho ${ }^{1}$, M.B.D. Bertéli ${ }^{1}$, J.S. Valle ${ }^{1}$, L.D. Paccola-Meirelles ${ }^{1}$, \\ G.A. Linde', F.G. Barcellos ${ }^{2}$ and N.B. Colauto ${ }^{1}$ \\ ${ }^{1}$ Programa de Pós-Graduação em Biotecnologia Aplicada à Agricultura, \\ Universidade Paranaense, Umuarama, PR, Brasil \\ ${ }^{2}$ Centro de Ciências Biológicas, Universidade Estadual de Londrina, \\ Londrina, PR, Brasil \\ Corresponding author: L.D. Paccola-Meirelles \\ E-mail: luziadoretto@prof.unipar.br
}

Genet. Mol. Res. 16 (2): gmr16029698

Received April 12, 2017

Accepted May 8, 2017

Published June 20, 2017

DOI http://dx.doi.org/10.4238/gmr16029698

Copyright $(2017$ The Authors. This is an open-access article distributed under the terms of the Creative Commons Attribution ShareAlike (CC BY-SA) 4.0 License.

\begin{abstract}
The genetic diversity of epiphytic yeasts from grape carposphere is susceptible to environmental variations that determine the predominant carposphere microbiota. Understanding the diversity of yeasts that inhabit grape carposphere in different environments and their pectinolytic activity is a way to understand the biotechnological potential that surrounds us and help improve winemaking. Therefore, this study aimed to evaluate the pectinolytic activity and characterize the genetic diversity of isolated epiphytic yeasts from grape carposphere. Grapes of the Bordeaux cultivar were collected from different regions of Paraná and Rio Grande do Sul States, in Brazil, and the yeasts were isolated from these grape carpospheres. Monosporic isolates were morphologically and genetically characterized on potato dextrose agar medium and by PCR-RFLP and rep-PCR (BOX-PCR) in the ITS15.8S-ITS2 region of rDNA. The index of pectinolytic activity of isolates was also evaluated estimating the ratio between the halo diameter of enzymatic degradation and the diameter of the colony when the isolates
\end{abstract}

Genetics and Molecular Research 16 (2): gmr16029698 
were grown in cultivation medium containing $10 \mathrm{~g} / \mathrm{L}$ pectin, $5 \mathrm{~g} / \mathrm{L}$ yeast extract, $15 \mathrm{~g} / \mathrm{L}$ agar, $0.12 \%$ (w/v) Congo red, and $\mathrm{pH}$ 6.2. We observed that the grape carposphere is an environment with a great genetic diversity of epiphytic yeasts of the following genera: Cryptococcus (31.25\%), Pichia (25.0\%), Candida (25.0\%), Dekkera (12.5\%), and Saccharomyces (6.25\%). The PCR-RFLP technique allowed analyzing existing polymorphism among individuals of a population based on a more restrict and evolutionarily preserved region, mostly utilized to differentiate isolates at the genus level. Approximately 33\% of yeast isolates presented pectinolytic activity with potential biotechnological for wine and fruit juice production. This great genetic variability found indicated that it is a potential reservoir of genes to be applied in viniculture improvement programs.

Key words: Biotechnology; Yeast; Taxonomy; BOX-PCR; PCR-RFLP; Ribosomal DNA

\section{INTRODUCTION}

The first grapevine varieties cultivated in Brazil were Vitis vinifera L., introduced by the Portuguese, and Vitis labrusca L., introduced by the Italian. Among V. labrusca, Bordeaux cultivar has stood out for its capacity to adapt to Brazilian climatic conditions, high productivity, and tolerance to fungal diseases (Rizzon et al., 2000). It also stands out for the production of a must with intense color and high acidity. This cultivar is mainly utilized for the production of juices and fine wines (Pommer, 2003).

Several factors are involved in the production of high-quality wine such as the grape cultivar, the cultivation environment, culture management, wild yeast strains involved in the fermentation process besides the yeast strain used in winemaking. Yeast is the responsible agent for the transformation of must sugar into alcohol during the fermentation process to produce wine, producing and releasing pectinases that with $\beta$-glucanases and hemicellulases help the extraction, clearing, and stabilization of wine, resulting in improvement in its quality and stability (Bhat, 2000; Takayanagi et al., 2001). According to Gump and Halght (1995), pectinases reduce winemaking costs due to the elimination and/or substitution of enhancers in grape processing and winemaking, increasing productivity.

Winemaking is a complex process that involves the sequential development of different yeast species (Sabate et al., 2002) mostly found in grape carposphere. The surface of ripe grapes has a microbial community that varies from $10^{3}$ to $10^{5} \mathrm{CFU} / \mathrm{g}$, and most of them are yeasts and lactic and acetic bacteria (Fleet, 1999). As soon as a grape is crushed and its content is released, the natural fermentation process occurs due to yeasts that are naturally found in grape carposphere. The population of yeasts related with grape carposphere depends on grape variety, its maturation level, and grapevine geographical location (Sabate et al., 2002). According to Sabate et al. (2002), yeasts that are found in grape carposphere are the predominant microbiota of the must with development in the first stages of the fermentation process, having an important role in fermentation and quality of the final product. Therefore, it is essential to identify and characterize yeasts found on the grape carposphere to obtain better quality wine (Combina et al., 2005).

Genetics and Molecular Research 16 (2): gmr16029698 
The development of molecular techniques for DNA analysis such as PCR (polymerase chain reaction) and DNA sequencing allowed establishing strategies for more accurate taxonomic identification of microbial isolates (Barcellos and Hungria, 2010). For fungi, in general, including yeasts, the rDNA region (ITS1-5.8S-ITS2) has been utilized for the taxonomic identification of the genus and species through PCR-RFLP (Restriction Fragment Length Polymorphism) (Barcellos and Hungria, 2010). Despite having been developed for repetitive elements of prokaryotic genomes, the PCR of repetitive elements (rep-PCR) is also an identification option that has been utilized for eukaryotic genomes and in studies of diversity and taxonomy of yeasts (Loncaric et al., 2009).

The knowledge of pectinolytic yeast populations found in grape carposphere is relevant for the occurrence of a good fermentation process and a better quality of the final product. Thus, in this study, we characterize the genetic diversity and evaluate the pectinolytic activity of isolated epiphytic yeasts from grape carposphere of Bordeaux cultivar.

\section{MATERIAL AND METHODS}

\section{Grape harvest and yeast isolation}

Grapes (Vitis labrusca L.) of Bordeaux cultivar were harvested from five grapeproducing regions of Paraná State: Colombo, Marialva, Miqueleto, Santa Felicidade - Curitiba, and Warta - Londrina, and from six regions of Rio Grande do Sul State: Bento Gonçalves, Caxias do Sul, Farroupilha, Garibaldi, Pinto Bandeira, and Veranópolis, Brazil, and stored in a refrigerator. Whole grapes, without damages, were washed with autoclaved $\left(121^{\circ} \mathrm{C}\right.$ for $30 \mathrm{~min}$ ) distilled water under agitation for $250 \mathrm{rpm}$, for $30 \mathrm{~min}$, at $25^{\circ} \mathrm{C}$. Aliquots of $0.1 \mathrm{~mL}$ washing water were spread on potato dextrose agar medium (PDA). The isolated yeasts were purified until obtaining a pure culture, confirmed by visualization under an optical microscope and cryopreserved at $-80^{\circ} \mathrm{C}$ in culture medium containing Czapek-Dox broth (CBD) and glycerol (1:1). All isolated yeasts were deposited in the culture collection of the Department of General Biology of Londrina State University.

\section{Characterization of genetic diversity of isolated yeasts}

\section{Morphological characterization}

Colonies of isolated yeasts were grown on PDA medium for $72 \mathrm{~h}$ at $28^{\circ} \mathrm{C}$ and grouped according to the shape, size, elevation, color, consistency, and aspect of the margin of the colonies. The cell structures were observed under optical microscope and colonies were photographed and separated by different morphotypes.

\section{Extraction of genomic DNA}

A sample of each morphotype was selected for DNA extraction and molecular analysis. Each isolate was cultivated in YPD $(10 \mathrm{~g} / \mathrm{L}$ yeast extract, $20 \mathrm{~g} / \mathrm{L}$ peptone, and 20 $\mathrm{g} / \mathrm{L}$ dextrose) cultivation media for 3 days, washed in autoclaved $\left(121^{\circ} \mathrm{C}\right.$ for $\left.30 \mathrm{~min}\right)$ distilled water, and centrifuged at $12,000 \mathrm{~g}$. The formed pellet was re-suspended in $200 \mu \mathrm{L}$ lyse buffer (2\% Triton X-100, 1\% SDS, $100 \mathrm{mM} \mathrm{NaCl}, 10 \mathrm{mM}$ Tris-HCl, 1 mM EDTA, $\mathrm{pH}$ 8.0), 200

Genetics and Molecular Research 16 (2): gmr16029698 
$\mu \mathrm{L}$ phenol:chloroform:isoamyl alcohol (25:24:1) solution, and homogenized in a Vortex agitator with glass beads (Ausubel et al., 2002). After, $200 \mu \mathrm{L}$ Tris:EDTA (10:1), pH 8.0, was added and centrifuged at $12,000 \mathrm{~g}$ for $5 \mathrm{~min}$. The aqueous phase was transferred to a new tube with $1 \mathrm{~mL}$ cold absolute ethanol, centrifuged at $2000 \mathrm{~g}$, washed with $70 \%$ ethanol, centrifuged at $2000 \mathrm{~g}$, air dried at room temperature and solubilized in $50 \mu \mathrm{L}$ ultrapure water. The concentration and quality of extracted DNA were evaluated by electrophoresis on agarose gel at $0.8 \%(\mathrm{w} / \mathrm{v})$ in $0.5 \mathrm{X} \mathrm{TBE}$ buffer (Tris-Borate-EDTA) at $5 \mathrm{~V} / \mathrm{cm}$ for $90 \mathrm{~min}$. The gels were stained with ethidium bromide $(0.5 \mathrm{mg} / \mathrm{mL})$, according to Sambrook and Russell (2006), and the images were digitalized using an L-PIX EX photo documenter (Loccus Biotecnologia) under ultraviolet (UV) light.

\section{PCR}

Primers ITS1 (5'-TCCGTAGGTGAACCTGCGG-3') and ITS4 (5'-TCCTCCGCTTA TTGATATGC-3') were utilized to amplify the ITS1-5.8S-ITS2 region of rDNA. The mixture of PCR $(25 \mu \mathrm{L})$ consisted of PCR 1X buffer (Life Technologies), $0.2 \mathrm{mM}$ dNTP mixture, 1.5 $\mathrm{mM} \mathrm{MgCl}, 0.5$ pmol of each primer, $1.25 \mathrm{U}$ Taq DNA polymerase (Life Technologies) and 10 ng genomic DNA of each isolate. PCR was carried out in a thermocycler (Amplitherm Thermal Cyclers) with an initial denaturation cycle for $5 \mathrm{~min}$ at $95^{\circ} \mathrm{C}$, followed by 35 cycles of amplification $\left(94^{\circ} \mathrm{C} 1 \mathrm{~min}, 56^{\circ} \mathrm{C} 1 \mathrm{~min}, 72^{\circ} \mathrm{C} 1 \mathrm{~min}\right)$ and a final extension cycle for $5 \mathrm{~min}$ at $72^{\circ} \mathrm{C}$. To visualize the amplification products, $1 \mu \mathrm{L}$ final PCR product was submitted to electrophorese on $1 \%$ agarose gel (w/v) using the molecular mass marker of $1 \mathrm{~kb}$ plus DNA ladder (Life Technologies) and ethidium bromide (Sambrook and Russell, 2006). In all PCR reactions a tube containing all reagents, except for DNA sample, was utilized as a negative control.

\section{Restriction of amplification products of the ITS1-5.8S-ITS2 region of ribosomal DNA (PCR-RFLP)}

The enzymes utilized in the restriction analysis of the ITS1-5.8S-ITS2 region were HinfI, CfoI, and HaeIII. The digestion reaction $(15 \mu \mathrm{L})$ consisted of $1.5 \mu \mathrm{L} 10 \mathrm{X}$ digestion buffer, $3 \mathrm{U}$ enzyme, $2 \mu \mathrm{L}$ purified PCR product and ultrapure water to complete the volume. The digestions were done in a thermocycler (Amplitherm Thermal Cyclers) at $37^{\circ} \mathrm{C}$ for 90 min. The digestion product was applied in electrophorese gel with $2 \%$ agarose $(\mathrm{w} / \mathrm{v})$, using the molecular mass marker of $1 \mathrm{~kb}$ plus DNA ladder (Invitrogen) with ethidium bromide (Sambrook and Russell, 2006).

\section{DNA amplification by rep-PCR}

The primers described by Versalovic et al. (1991) were utilized for BOX-PCR (rep-PCR). PCR was carried out in a thermocycler (Amplitherm Thermal Cyclers) with a reaction volume of $30 \mu \mathrm{L}$ PCR mix REDTaq (20 mM Tris- $\mathrm{HCl}, 100 \mathrm{mM} \mathrm{KCl}, 3 \mathrm{mM} \mathrm{MgCl}, 0.4 \mathrm{mM} \mathrm{DNTP}, 0.9 \mathrm{U}$ Taq DNA polymerase, and $24 \mathrm{pM}$ primers for BOX-PCR). In DNA amplifications, initial denaturation (7 min) occurred at $95^{\circ} \mathrm{C}$, followed by 30 denaturation cycles $\left(1 \mathrm{~min}\right.$ at $\left.94^{\circ} \mathrm{C}\right)$, pairing for $1 \mathrm{~min}$ at $53^{\circ} \mathrm{C}$ and extension $\left(8 \mathrm{~min}\right.$ at $65^{\circ} \mathrm{C}$ ) with a final extension of $16 \mathrm{~min}$ at $65^{\circ} \mathrm{C}$. The PCR product $(15 \mu \mathrm{L})$ was submitted to electrophorese on $1.5 \%$ agarose gel $(\mathrm{w} / \mathrm{v})$ with molecular mass marker of $1 \mathrm{~kb}$ plus DNA ladder (Invitrogen) with ethidium bromide (Sambrook and Russell, 2006).

Genetics and Molecular Research 16 (2): gmr16029698 


\section{Dendrogram graph}

Based on band profiles obtained from rep-PCR and PCR-RFLP amplifications of the ITS1-5.8S-ITS2 region of rDNA, isolates were grouped by DendroUPGMA program (http:// genomes.urv.cat/UPGMA/; Garcia-Vallvé et al., 1999). A dendrogram construction was done utilizing UPGMA (unweighted pair-group method with arithmetic mean) algorithm (Sneath and Sokal, 1973) and Jaccard's coefficient at a tolerance level of 3\% (Barcellos et al., 2007).

\section{Pectinolytic activity of isolated yeasts}

The isolates were cultivated for 3 days at $28^{\circ} \mathrm{C}$ on PDA and transferred to cultivation medium consisting of $10 \mathrm{~g} / \mathrm{L}$ pectin, $5 \mathrm{~g} / \mathrm{L}$ yeast extract, $15 \mathrm{~g} / \mathrm{L}$ agar, and $0.12 \%(\mathrm{w} / \mathrm{v})$ Congo red, pH 6.2, for 10 days at $28^{\circ} \mathrm{C}$ (Akbar and Prasuna, 2012). Pectinolytic activity was evaluated adding $3 \mathrm{~mL} 1 \mathrm{M} \mathrm{HCl}$ solution to the cultivation medium. The visualization of light halos around the colonies indicated substrate hydrolysis by pectinolytic activity. The enzymatic activity index was estimated by the ratio between the degradation halo and the colony diameter (Hankin and Anagnostakis, 1975). Assays were done in triplicate and reported as arithmetic average and standard deviation.

\section{RESULTS AND DISCUSSION}

\section{Characterization of genetic diversity of isolated yeasts}

\section{Morphological characterization of isolated yeasts}

Isolated yeasts (90) were morphologically characterized as Saccharomyces and non-Saccharomyces genera. Morphotypes presented differentiations in shape, texture, and shine of colonies with white, salmon, cream, or orange (Figure 1), and shiny or opaque (Figure 2) chromogenesis. The isolates were grouped based on morphological aspects in 18 morphologically distinct groups. A representative of each of these groups was selected for morphological analysis of the colony (Table 1), and a great morphological variability was observed, mainly in the regions of Colombo and Farroupilha (Figure 3).

\section{CHROMOGENESIS}

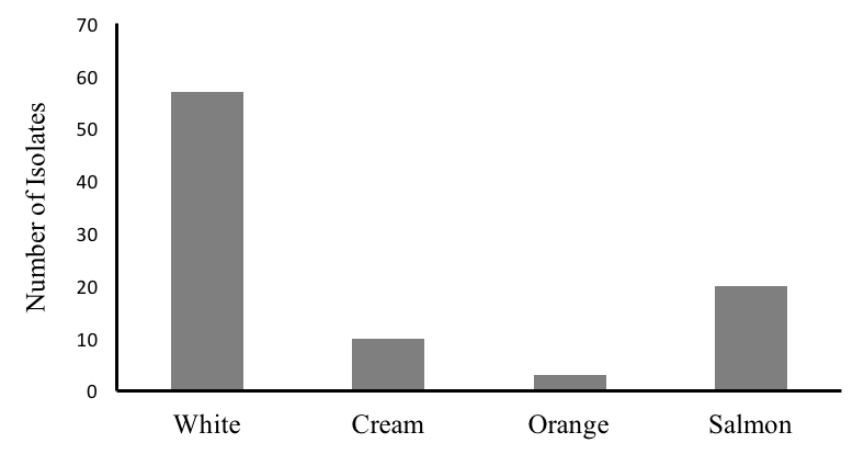

Figure 1. Chromogenesis of isolated yeast colonies of grape carposphere. 


\section{CHROMOGENESIS}

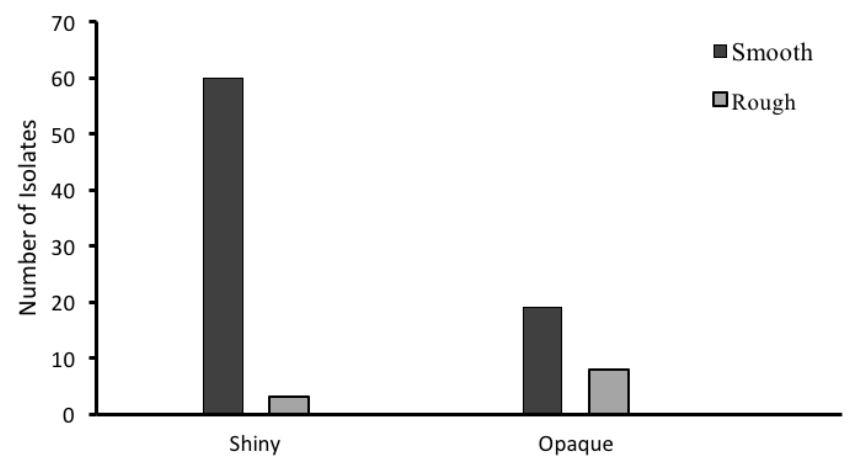

Figure 2. Optical detail and surface of isolated yeast colonies of grape carposphere.

Table 1. Morphological description of isolated yeasts from grape carposphere, based on macroscopic observations.

\begin{tabular}{|c|c|c|c|c|c|c|c|}
\hline \multirow[t]{2}{*}{ Isolate } & \multicolumn{7}{|c|}{ Morphology of colonies } \\
\hline & Form & Elevation & Margin & Chromogenesis & Optical detail & Surface & Consistency \\
\hline Ub01 & Irregular & Flat & Undulate & Salmon & Shiny & Smooth & Mucoid \\
\hline $\mathrm{Ub02}$ & Irregular & Flat & Undulate & White & Opaque & Smooth & Dry \\
\hline $\mathrm{Ub03}$ & Irregular & Flat & Undulate & White & Shiny & Smooth & Mucoid \\
\hline Ub04 & Circular & Flat & Entire & White & Opaque & Smooth & Mucoid \\
\hline Ub05 & Irregular & Raised & Lobate & White & Shiny & Rough & Gummy \\
\hline Ub06 & Circular & Flat & Undulate & White & Shiny & Smooth & Mucoid \\
\hline Ub07 & Circular & Flat & Entire & White & Shiny & Smooth & Mucoid \\
\hline Ub08 & Rhizoid & Flat & Undulate & Cream & Shiny & Smooth & Mucoid \\
\hline Ub09 & Irregular & Flat & Undulate & Salmon & Opaque & Rough & Dry \\
\hline Ub10 & Irregular & Convex & Lobate & Salmon & Shiny & Smooth & Gummy \\
\hline Ub11 & Irregular & Flat & Lobate & White & Opaque & Smooth & Dry \\
\hline Ub12 & Irregular & Flat & Undulate & White & Opaque & Smooth & Gummy \\
\hline Ub13 & Irregular & Umbonate & Lobate & White & Opaque & Rough & Powdery \\
\hline Ub14 & Circular & Flat & Entire & Salmon & Shiny & Smooth & Mucoid \\
\hline Ub16 & Circular & Convex & Entire & Salmon & Shiny & Smooth & Gummy \\
\hline Ub17 & Rhizoid & Flat & Filiform & Orange & Opaque & Rough & Dry \\
\hline Ub18 & Rhizoid & Flat & Filiform & White & Opaque & Smooth & Dry \\
\hline $\mathrm{Ub} 22$ & Circular & Flat & Entire & Cream & Shiny & Smooth & Mucoid \\
\hline
\end{tabular}

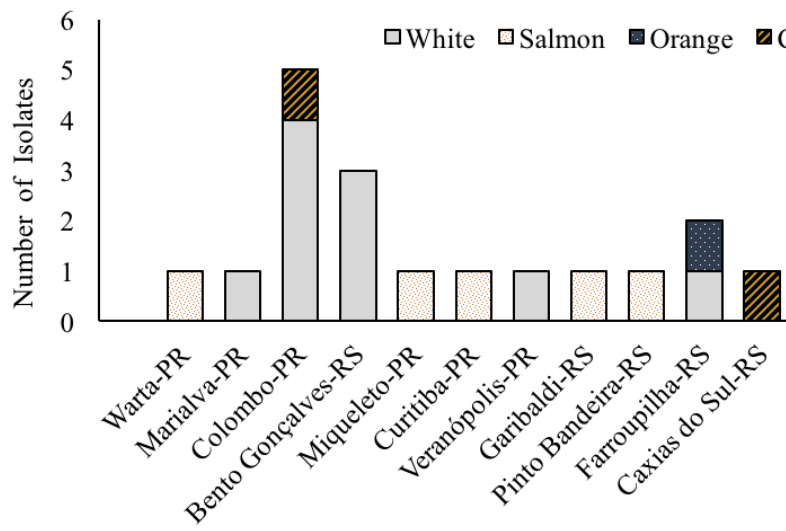

Figure 3. Number of isolated yeasts and morphotypes (colony color) collected from grape carposphere in different regions of Paraná (PR) and Rio Grande do Sul (RS) States, in Brazil.

Genetics and Molecular Research 16 (2): gmr16029698 
Phenotypical characters and the number of yeasts can be affected by cultivation conditions, cultivar, harvesting period, climatic conditions, geographic location, stage of fruit ripening, the presence of physical damages, and the utilization of agricultural pesticides in grapes (Mortimer and Polsinelli, 1999); this can partly explain the greater morphological variability observed in the isolated yeasts. Moreover, the morphological variation makes yeast characterization by morphological characteristics difficult; therefore, the molecular technique becomes the most appropriate technique for a more accurate taxonomic classification (Tofalo et al., 2009).

\section{Molecular (taxonomic) identification of yeasts}

According to the morphological cluster, a representative isolate of each morphotype was selected for the taxonomic identification (genus). Based on the amplification of the ITS1-5.8S-ITS2 region of rDNA, the amplicons ranged from 425 to $850 \mathrm{bp}$. The fragments amplified by PCR (Figure 4) were digested with CfoI, Hinfl, and HaeIII restriction enzymes and the generated band profiles are shown in Table 2. These patterns were compared to the ones described by Esteve-Zarzoso et al. (1999).

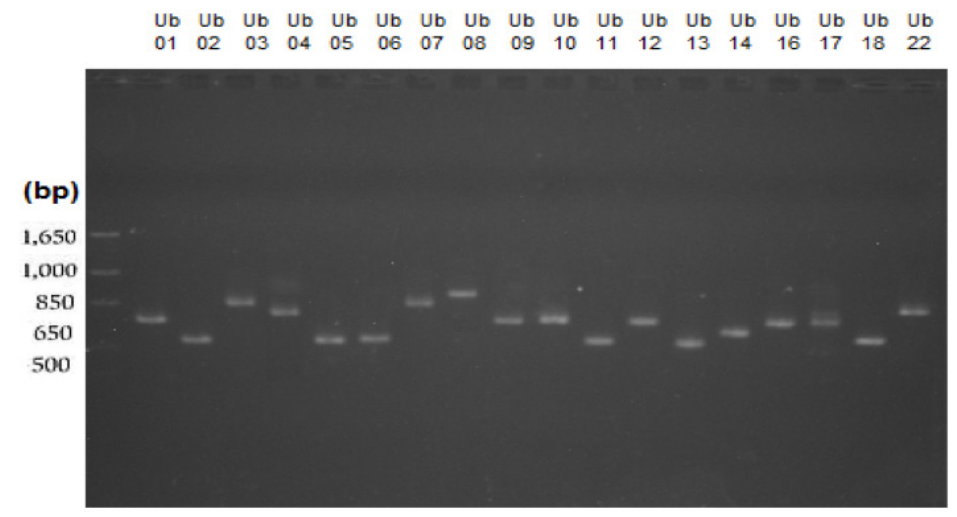

Figure 4. Amplicons (bp) of the ITS1-5.8S-ITS2 region of rDNA obtained by PCR of isolated yeasts of grape carposphere.

Table 2. Size (bp) of PCR and PCR-RFLP products and identification of isolated yeast genera of grape carposphere.

\begin{tabular}{|c|c|c|c|c|c|}
\hline \multirow[t]{2}{*}{ Genus } & \multirow[t]{2}{*}{ Isolate code } & \multirow[t]{2}{*}{ ITS* (bp) } & \multicolumn{3}{|c|}{ Fragments of enzymatic restriction } \\
\hline & & & CfoI & HaeIII & HinfI \\
\hline Cryptococcus & Ub01 & 660 & $345+315$ & $400+70+70+60+60$ & $370+290$ \\
\hline Pichia & $\mathrm{Ub02}$ & 500 & $175+110+90+75$ & $330+90+50$ & $275+200$ \\
\hline Dekkera & Ub03 & 800 & $340+340+120$ & 800 & $360+190+160+80$ \\
\hline Candida & Ub05 & 580 & 510 & $370+190$ & $290+260$ \\
\hline Candida & Ub06 & 580 & 510 & $370+190$ & $290+260$ \\
\hline Dekkera & Ub07 & 800 & $340+340+120$ & $375+95$ & $270+215$ \\
\hline Saccharomyces & Ub08 & 880 & $385+365$ & $500+220+145$ & $365+155$ \\
\hline Cryptococcus & Ub09 & 630 & $330+300$ & $500+70+60$ & $350+280$ \\
\hline Cryptococcus & Ub10 & 630 & $330+300$ & $500+70+60$ & $350+280$ \\
\hline Pichia & Ub11 & 500 & $260+180+60$ & 500 & $270+230$ \\
\hline Candida & Ub13 & 425 & 400 & 425 & $225+200$ \\
\hline Candida & Ub14 & 550 & $300+240$ & $400+115$ & $290+260$ \\
\hline Cryptococcus & Ub16 & 630 & $330+300$ & $500+70+60$ & $350+280$ \\
\hline Cryptococcus & Ub17 & 630 & 630 & $505+65+60$ & $235+150+135+110$ \\
\hline Pichia & Ub18 & 500 & $260+180+60$ & 500 & $270+230$ \\
\hline Pichia & Ub22 & 650 & 575 & $600+50$ & $310+310$ \\
\hline
\end{tabular}

*Amplicon size obtained by PCR of the ITS1-5.8S-ITS2 region of ribosomal DNA. 
According to Skinner et al. (1980) and Phaff (1990), grape carposphere consists mainly of yeast-like fungi such as Aureobasidium, Rhodotorula, Cryptococcus, Candida, Pichia, Hanseniaspora, and Saccharomyces genera, similar to most genera found in our study (Table 2). Other authors also cite the presence of Saccharomyces cerevisiae, Candida valida, Kloeckera apiculata and Pichia membranifaciens on the grape carposphere (Mamede and Pastore, 2004; Fernandes et al., 2008).

Pichia genus was found at the rate of $25 \%$ of isolates (Table 3 ). This genus contributed to the increase in wine aroma by synthesizing enzymes such as $\beta$-glucosidase (Maicas and Mateo, 2005). Lopes et al. (2009) found this genus in the initial stages of the grape fermentation process and consider it one of the responsible for the organoleptic properties of wine.

Table 3. Genus of isolated yeasts found in grape carposphere and respective isolation frequencies.

\begin{tabular}{|c|c|c|}
\hline Traits & $\mathrm{P}$ & $\mathrm{G}$ \\
\hline Direct effect of NNB on Y & 0.070 & -0.379 \\
\hline Indirect effect via NBN & 0.136 & 0.921 \\
\hline Indirect effect via NP2 & 0.119 & 0.501 \\
\hline Indirect effect via NP3 & 0.034 & 0.053 \\
\hline Indirect effect via TNP & 0.070 & -0.528 \\
\hline Total & 0.432 & 0.5683 \\
\hline Direct effect of NBN on Y & 0.204 & 1.183 \\
\hline Indirect effect via NNB & 0.047 & -0.295 \\
\hline Indirect effect via NP2 & 0.127 & 0.492 \\
\hline Indirect effect via NP3 & 0.115 & 0.216 \\
\hline Indirect effect via TNP & 0.115 & -0.86 \\
\hline Total & 0.6107 & 0.7324 \\
\hline Direct effect of NP2 on Y & 0.288 & 1.039 \\
\hline Indirect effect via NNB & 0.029 & -0.183 \\
\hline Indirect effect via NBN & 0.090 & 0.559 \\
\hline Indirect effect via NP3 & 0.055 & -0.237 \\
\hline Indirect effect via TNP & 0.117 & -0.768 \\
\hline Total & 0.5808 & 0.4099 \\
\hline Direct effect of NP3 on Y & 0.534 & 1.123 \\
\hline Indirect effect via NNB & 0.004 & -0.018 \\
\hline Indirect effect via NBN & 0.044 & 0.228 \\
\hline Indirect effect via NP2 & 0.029 & -0.220 \\
\hline Indirect effect via TNP & 0.931 & 0.467 \\
\hline Total & 0.7061 & 0.6454 \\
\hline Direct effect of TNP on Y & 0.163 & -1.101 \\
\hline Indirect effect via NNB & 0.030 & -0.182 \\
\hline Indirect effect via NBN & 0.144 & 0.928 \\
\hline Indirect effect via NP2 & 0.206 & 0.725 \\
\hline Indirect effect via NP3 & 0.304 & 0.477 \\
\hline Total & 0.8494 & 0.8472 \\
\hline Determination coefficient & 0.83 & 0.86 \\
\hline Residual effect & 0.40 & 0.36 \\
\hline
\end{tabular}

The most abundant genus observed in our study was Cryptococcus representing $31.25 \%$ of isolates (Table 3) and characterized by encapsulated yeasts that form pigmented colonies.

Candida genus was identified in $25 \%$ of isolates (Table 3 ). Yeasts of this genus have a potential for alcoholic fermentation of pentose (Du Preez et al., 1986); moreover, some species have an antifungal activity that controls wine contamination by filamentous fungi (Fleet, 2003).

Approximately $12 \%$ of isolates belong to Dekkera genus (Table 3). According to Esteve-Zarzoso et al. (1999), Dekkera bruxellensis is among the species that cause the greatest impact on wine quality by producing non-desirable aromatic compounds and is isolated from grape carposphere or in the wood barrel during the storage or aging of wines.

Genetics and Molecular Research 16 (2): gmr16029698 
Saccharomyces genus, as reported by other authors (Martini, 1993; Pretorius, 2000), was observed at low frequency, only $6.25 \%$ (Table 3). According to Barata et al. (2012), this yeast, despite being very utilized in fermentation processes of wine production, is isolated in a smaller number when a direct isolation technique is used, suggesting that it is less frequent in grape carposphere. According to Fleet (1999), the number of fermentative yeasts such as Saccharomyces spp is greater when the grape skin is damaged, releasing its content to the grape carposphere, resulting in a population increase of $10^{6}$ to $10^{8} \mathrm{CFU} / \mathrm{g}$ when compared to undamaged grapes.

\section{Analysis of genetic diversity of isolated yeast based on dendrograms obtained by BOX-PCR and PCR-RFLP in the ITS1-5.8S-ITS2 region of rDNA}

BOX-PCR genomic marker differentiated nine groups (A, B, C, D, E, F, G, H, I) and two subgroups $\left(\mathrm{B}_{1}\right.$ and $\left.\mathrm{B}_{2}\right)(\geq 50 \%$ similarity) (Figure 5). Group $\mathrm{A}$ was the only representative of Warta region (Londrina - PR), from Cryptococcus genus, and that presented colonies with salmon chromatogenesis and mucoid consistency. Group B, consisting of Pichia genus, presented two subgroups (Figure 5). $\mathrm{B}_{1}$ was isolated in the region of Paraná State and, $\mathrm{B}_{2}$ in the region of Rio Grande do Sul State. The chromatogenesis presented in the group colony was white with a dry consistency. The similarity among the subgroups was $60 \%$. Group C, represented by Saccharomyces genus, was the only one from Colombo - PR and whose colony chromatogenesis had cream color with a mucoid consistency (Figure 5). Group D, consisting of two representatives of Cryptococcus genus, had a similarity of $66.7 \%$ and was from Curitiba - PR. They presented salmon chromatogenesis, but the colonies were different on the surface: Ub09 was rough and Ub10 was smooth. Group E (Figure 5), represented by Pichia genus, showed cream color chromatogenesis with mucoid consistency and was from Caxias do Sul - RS. Group F, represented by Cryptococcus genus (Ub16), was different from the other representatives of this genus (Ub01, Ub09, Ub10, Ub17) because its colonies had white chromatogenesis with mucoid consistency. Group G, consisting of Candida genus, with $75 \%$ of similarity, were all from Bento Gonçalves - RS, and had white colonies, differentiating themselves only by the consistency: UB05 was mucoid and Ub13 was dry (Figure 5 and Table 1). Group H, represented by Candida genus (Figure 5 and Table 1), with a single isolate from Garibaldi - RS, had colonies with salmon chromatogenesis and dry consistency. Group I, Cryptococcus genus, was the only isolate from Farroupilha - RS and presented colonies with orange chromatogenesis and dry consistency.

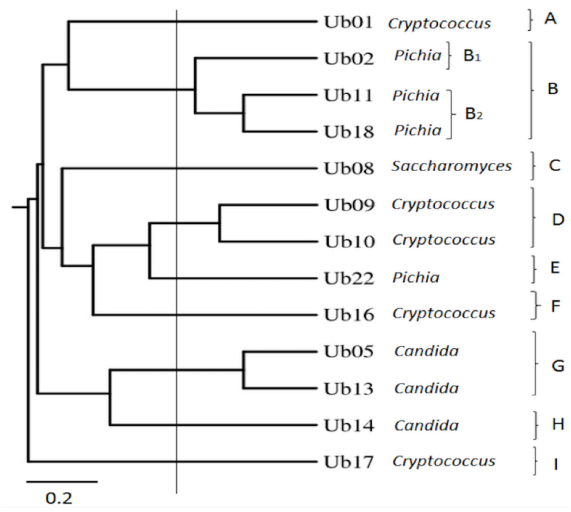

Figure 5. Cluster by BOX-PCR with analysis from the level at 50\% similarity of isolated yeasts of grape carposphere.

Genetics and Molecular Research 16 (2): gmr16029698 
The BOX-PCR technique, due to polymorphism generated in several regions of the genome, allowed differentiating genotypes. The PCR-RFLP technique in the ITS1-5.8S-ITS2 region analyzed the existing polymorphism among individuals of a population based on a more restricted and evolutionarily preserved region, which allowed the differentiation of isolates at the genus or superior taxonomic levels (Barcellos and Hungria, 2010). In our study, it was observed that most of the obtained clusters were formed by only one or two isolates, showing a high genetic diversity. Also, the isolated yeasts belonging to each group were from distinct regions where the grape was collected.

The analysis of restriction of the ITS1-5.8S-ITS2 region by the PCR-RFLP technique allowed observing the formation of nine groups (I, II, III, IV, V, VI, VII, VIII, IX) (Figure 6) with similarity level over $80 \%$. Similarly to the clusters obtained by BOX-PCR, most of the formed groups consisted of only one of two isolates. In groups V and VI, the isolates were grouped at 100\% similarity, and they were from Pichia and Cryptococcus genera, respectively.

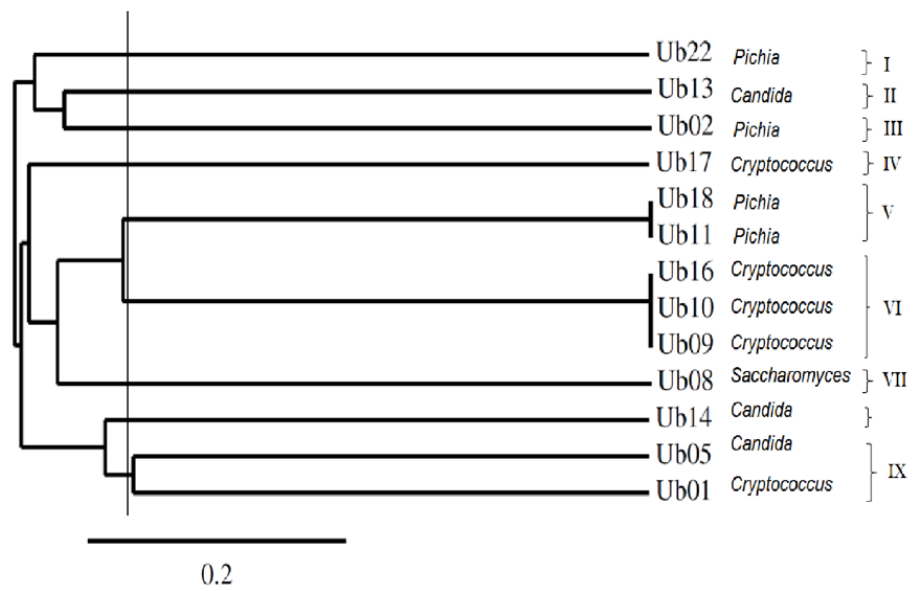

Figure 6. Cluster by PCR-RFLP with analysis from the level at $80 \%$ similarity of isolated yeasts of grape carposphere.

Comparing the cluster formed by BOX-PCR and PCR-RFLP, six groups presented the same similarity indexes, except for groups II, III, and IX that presented significant similarities. Therefore, it was possible to verify that isolated yeasts presented a broad genetic diversity, which potentially implies in potential future use for bioprospecting studies.

The exclusive utilization of morphological, biological, and physiological criteria to identify microbial communities is questionable due to their heterogeneous phenotypical results. The reproducibility of these methodologies is questionable as a result depends on the physiological state of the cell at that moment (Barata et al., 2012). However, despite being nonconclusive, these techniques can help and complement molecular techniques of identification. Molecular techniques directly analyze the individual genome, regardless of the physiological state of the cell, which allows a greater accuracy in the identification (Fernández-Espinar et al., 2011; Barata et al., 2012).

Our results indicated that the grape carposphere has a great variety of yeast species that, according to Pretorius et al. (1999), can spontaneously ferment sugars and generate 
ethanol, carbon dioxide, and other metabolites, and can contribute to change the quality of the final product. Several factors such as temperature can affect yeast diversity on the grape carposphere (Rementeria et al., 2003). This genetic variability is a potential genetic reservoir for yeast breeding programs for winemaking, which contribute to the quality of the final product such as the aroma (Pretorius, 2004).

\section{Pectinolytic activity}

The isolated yeasts in our study presented potential to produce pectinases, and $33 \%$ of them presented enzymatic activity index over 2.0 (Table 3), which, according to Lealem and Gashe (1994), would be the minimum value to consider a microorganism an enzyme producer. Pectinases are utilized in several biotechnological areas, mainly in the food industry for maceration of vegetal tissues (Lea, 1995), extraction, and clarification of juices and wines (Hoondal et al., 2002). They are responsible for the hydrolysis of the cell wall releasing anthocyanins, which are pigments that confer a reddish color of fruits, and that are widely utilized in the production of red wine with reduction of maceration time of grape bark in the must (Kashyap et al., 2001).

\section{CONCLUSION}

The grape carposphere is an environment with a great genetic diversity of yeasts of Cryptococcus (31.25\%), Pichia (25.0\%), Candida (25.0\%), Dekkera (12.5\%), and Saccharomyces (6.25\%) genera. PCR-RFLP technique allowed analyzing the polymorphism among individuals of a population based on a more restricted and evolutionarily preserved region and utilized mostly to differentiate isolates at the genus level. Most of the isolated yeasts $(33 \%)$ present pectinolytic activity with potential biotechnological application in the production of wines and fruit juices. The great genetic variability of isolates indicates a potential genetic reservoir for viniculture improvement programs.

\section{Conflicts of interest}

The authors declare no conflict of interest.

\section{ACKNOWLEDGMENTS}

The authors thank Prof. Dr. Maria Helena Fungaro for the availability of collected biological material, and Universidade Paranaense, Universidade Estadual de Londrina, CAPES, and CNPq for the support.

\section{REFERENCES}

\footnotetext{
Akbar S and Prasuna RG (2012). Exploitation of fruit wastes for pectinase production using Aspergillus oryzae. Int. J. Pharma Biol. Sci. 3: 756-765.

Ausubel FM, Brent R, Kingston RE, Moore DD, et al. (2002). Short protocols in molecular biology. 4th edn. John Wiley and Sons Inc., New York.

Barata A, Malfeito-Ferreira M and Loureiro V (2012). The microbial ecology of wine grape berries. Int. J. Food Microbiol. 153: 243-259. https://doi.org/10.1016/j.ijfoodmicro.2011.11.025
}

Genetics and Molecular Research 16 (2): gmr16029698 
Barcellos FG and Hungria M (2010). Técnicas moleculares aplicadas ao estudo da diversidade e à identificação de bactérias e fungos de interesse agrícola. In: Biotecnologia aplicada à agricultura (Figueiredo MVB, Burity HA, Oliveira JA, Santos CERS, et al., eds.). Embrapa Informação Tecnológica, Brasília.

Barcellos FG, Menna P, da Silva Batista JS and Hungria M (2007). Evidence of horizontal transfer of symbiotic genes from a Bradyrhizobium japonicum inoculant strain to indigenous diazotrophs Sinorhizobium (Ensifer) fredii and Bradyrhizobium elkanii in a Brazilian Savannah soil. Appl. Environ. Microbiol. 73: 2635-2643. https://doi. org/10.1128/AEM.01823-06

Bhat MK (2000). Cellulases and related enzymes in biotechnology. Biotechnol. Adv. 18: 355-383. https://doi.org/10.1016/ $\underline{\mathrm{S} 0734-9750(00) 00041-0}$

Combina M, Mercado L, Borgo P, Elia A, et al. (2005). Yeasts associated to Malbec grape berries from Mendoza, Argentina. J. Appl. Microbiol. 98: 1055-1061. https://doi.org/10.1111/j.1365-2672.2005.02540.x

Du Preez JC, Bosch M and Prior BA (1986). The fermentation of hexose and pentose sugars by Candida shehatae and Pichia stipitis. Appl. Microbiol. Biotechnol. 23: 228-233. https://doi.org/10.1007/BF00261920

Esteve-Zarzoso B, Belloch C, Uruburu F and Querol A (1999). Identification of yeasts by RFLP analysis of the 5.8S rRNA gene and the two ribosomal internal transcribed spacers. Int. J. Syst. Bacteriol. 49: 329-337. https://doi. org/10.1099/00207713-49-1-329

Fernandes SC, Osório REHMB, Anjos A, Neves A, et al. (2008). Determination of catechin in green tea using a catechol oxidase biomimetic sensor. J. Braz. Chem. Soc. 19: 1215-1223. https://doi.org/10.1590/S0103-50532008000600024

Fernández-Espinar MT, Llopis S, Querol A and Barrio E (2011). Molecular identification and characterization of wine yeasts. In: Molecular Wine Microbiology (Carrascosa AV, Muñoz R and González R, eds.). Elsevier, Academic Press, London.

Fleet GH (1999). Microorganisms in food ecosystems. Int. J. Food Microbiol. 50: 101-117. https://doi.org/10.1016/S0168$\underline{1605(99) 00080-X}$

Fleet GH (2003). Yeast interactions and wine flavour. Int. J. Food Microbiol. 86: 11-22. https://doi.org/10.1016/S0168$\underline{1605(03) 00245-9}$

Garcia-Vallvé S, Palau J and Romeu A (1999). Horizontal gene transfer in glycosyl hydrolases inferred from codon usage in Escherichia coli and Bacillus subtilis. Mol. Biol. Evol. 16: 1125-1134. https://doi.org/10.1093/oxfordjournals. molbev.a026203

Gump BH and Halght KG (1995). A preliminary study of industrial enzyme preparations for color extration/stability in red wines. In: Cati publication 950901. Viticulture and Enology Research Center, California State University, Fresno.

Hankin L and Anagnostakis S (1975). The use of solid media for detection of enzyme production by fungi. Mycologia 67: 597-607. https://doi.org/10.2307/3758395

Hoondal GS, Tiwari RP, Tewari R, Dahiya N, et al. (2002). Microbial alkaline pectinases and their industrial applications: a review. Appl. Microbiol. Biotechnol. 59: 409-418. https://doi.org/10.1007/s00253-002-1061-1

Kashyap DR, Vohra PK, Chopra S and Tewari R (2001). Applications of pectinases in the commercial sector: a review. Bioresour. Technol. 77: 215-227. https://doi.org/10.1016/S0960-8524(00)00118-8

Lea AGH (1995). Enzymes in the production of beverages and fruit juices. In: Enzymes in Food Processing (Tucker GA and Woods LFJ, eds.) Blackie Academic \& Professional, London.

Lealem F and Gashe BA (1994). Amylase production by a Gram-positive bacterium isolated from fermenting tef. (Eraglostis tef.). J. Appl. Microbiol. 77: 348-352.

Loncaric I, Oberlerchner JT, Heissenberger B and Moosbeckhofer R (2009). Phenotypic and genotypic diversity among strains of Aureobasidium pullulans in comparison with related species. Antonie van Leeuwenhoek 95: 165-178. https://doi.org/10.1007/s10482-008-9300-9

Lopes CA, Jofré V and Sangorrín MP (2009). Spoilage yeasts in Patagonian winemaking: molecular and physiological features of Pichia guilliermondii indigenous isolates. Rev. Argent. Microbiol. 41: 177-184.

Maicas S and Mateo JJ (2005). Hydrolysis of terpenyl glycosides in grape juice and other fruit juices: a review. Appl. Microbiol. Biotechnol. 67: 322-335. https://doi.org/10.1007/s00253-004-1806-0

Mamede MEO and Pastore GM (2004). Avaliação da produção dos compostos majoritários da fermentação de mosto de uva por leveduras isoladas da região da "Serra Gaúcha" (RS). Food Sci. Technol. (Campinas) 24: 453-458. https:// doi.org/10.1590/S0101-20612004000300026

Martini A (1993). Origin and domestication of the wine yeast Saccharomyces cerevisiae. J. Wine Res. 4: 165-176. https:// doi.org/10.1080/09571269308717966

Mortimer R and Polsinelli M (1999). On the origins of wine yeast. Res. Microbiol. 150: 199-204. https://doi.org/10.1016/ $\underline{\text { S0923-2508(99)80036-9 }}$

Phaff HJ (1990). Isolation of yeasts from natural sources. In: Isolation of Biotechnological Organisms from Nature (Labeda DP, ed.). McGraw-Hill Publ. Co., New York.

Genetics and Molecular Research 16 (2): gmr16029698 
Pommer CV (2003). Uva: Tecnologia de produção, pós-colheita, mercado. Cinco Continentes Editora Ltda., Porto Alegre. Pretorius IS (2000). Tailoring wine yeast for the new millennium: novel approaches to the ancient art of winemaking. Yeast 16: 675-729. https://doi.org/10.1002/1097-0061(20000615)16:8<675::AID-YEA585>3.0.CO;2-B

Pretorius IS (2004). The genetic improvement of wine yeasts. In: Handbook of fungal biotechnology (Arora DK, Bridge PD and Bhatnagar D, eds.). Marcel Dekker, New York.

Pretorius IS, Van Der Westhuizen TJ and Augustyn OPH (1999). Yeast biodiversity in vineyards and wineries and its importance to the South African wine industry. A Review. S. Afr. J. Enol. Vitic. 20: 61-74.

Rementeria A, Rodriguez JA, Cadaval A, Amenabar R, et al. (2003). Yeast associated with spontaneous fermentations of white wines from the "Txakoli de Bizkaia" region (Basque Country, North Spain). Int. J. Food Microbiol. 86: 201207. https://doi.org/10.1016/S0168-1605(03)00289-7

Rizzon LA, Miele A and Meneguzzo J (2000). Avaliação da uva cv. Isabel para a elaboração de vinho tinto. Food Sci. Technol. (Campinas) 20: 115-121. https://doi.org/10.1590/S0101-20612000000100022

Sabate J, Cano J, Esteve-Zarzoso B and Guillamón JM (2002). Isolation and identification of yeasts associated with vineyard and winery by RFLP analysis of ribosomal genes and mitochondrial DNA. Microbiol. Res. 157: 267-274. https://doi.org/10.1078/0944-5013-00163

Sambrook J and Russell DW (2006). The basic polymerase chain reaction. Protoc., Cold Spring Harbour.

Skinner FA, Passmore SM and Davenport RR (1980). Biology and activities of yeasts. 2nd edn. Academic Press, London.

Sneath PH and Sokal RR (1973). Numerical taxonomy. The principles and practice of numerical classification. W H Freeman \& Co., San Francisco.

Takayanagi T, Uchibori T and Yokutsuka K (2001). Characteristics of yeast polygalacturonases induced during fermentation on grapes skins. Am. J. Enol. Vitic. 52: 41-44.

Tofalo R, Chaves-López C, Di Fabio F, Schirone M, et al. (2009). Molecular identification and osmotolerant profile of wine yeasts that ferment a high sugar grape must. Int. J. Food Microbiol. 130: 179-187. https://doi.org/10.1016/j. ijfoodmicro.2009.01.024

Versalovic J, Koeuth T and Lupski JR (1991). Distribution of repetitive DNA sequences in eubacteria and application to fingerprinting of bacterial genomes. Nucleic Acids Res. 19: 6823-6831. https://doi.org/10.1093/nar/19.24.6823 